(平成 7 年 4 月 28 日受理)

\title{
毛髮の粘弾性的性質に及ぼす水の影響
}

\author{
サンスター株式会社 太田 裕子・福増 章夫 \\ 大妻女子大家政学部 西村 優子 - 中村 邦雄
}

\section{The Effect of Water Molecules on Viscoelastic Properties of Human Hair}

\author{
Yuko Ota ${ }^{* 1}$, Akio Fukumashi ${ }^{* 1}$, Yuko Nishimura ${ }^{* 2}$, and Kunio Nakamura ${ }^{* 2}$ \\ * Hair Care R \& D Division, SUNSTAR INC., 5-30-1, Kamihamuro, Takatsuki, Osaka, 569 Japan \\ *22 Otsuma Women's University, 12 Sanban-cho, Chiyoda-ku, Tokyo, 102 Japan
}

\begin{abstract}
The effects of water on viscoelastic properties of human hair were investigated by dynamic mechanical analysis (DMA) and differential scanning calorimetry (DSC). Dynamic modulus (E') of dry human hair decreased linearly with increasing temperature. On the other hand, $E^{\prime}$ of wet human hair showed an inflection point near 0 ${ }^{\circ} \mathrm{C}$. Moreover, a new dispersion peak was observed in $\tan \delta$ curves of human hair containing water molecules. The DMA curves of thioglicolic acid-treated human hair were similar to those of untreated human hair. Therefore, it was found that hydrogen bonds between protein chains in human hair acted more prominently than disulfide linkage ( $S$ - $S$ linkage). The glass transition temperature $(\mathrm{Tg})$ of human hair decreased with increasing absorbed wa ter content (Wc) and then saturated at about $30 \%$ of Wc. The non-freezing water content (Wnf) of human hair measured by. DSC was about $30 \%$. This means that physical properties of human hair such as $\mathrm{Tg}$ and strength are controlled by bound water which is strongly restricted by hydrophilic groups of proteins.
\end{abstract}

(Received April 28, 1995)

\section{1.はじめに}

美しく健やかな鬅を実現するへアケア商品の開発にお いて，対象となる毛嫒の各種の特性を把提することは， 重要な課題である。従ってこれまでに成分分析 [1，2] や形態観察 [3]をはじめ種々の角度から研究が進められ てきた。我々も毛髮の官能に関わりの深い物理的特性に 関して，静的試験である引張り試験を行い，毛抷の物性 に及は水の影響について検討してきた[4]。その結果， 水中では空気中に比心降伏点の応力が低下することをは じめ，応力ー歪み曲線に大きな違いが現れることを確諗 した。また各種織維の強伸度特性が、強く氷の影響を受 けること [5]，さらに物性に影䈉する本分子がすべて束 縛水であることなどを明らかにしてきた[6]。しかし静 的試験だけでは得られる情報に限りがあるため，今回は 動的粘弾性試娩などの熱的方法（DMA，DSC， $\mathrm{T}_{\mathrm{G}}$ ）を用 いて，毛媛の粘弾性的性質に及はすす水の影響およびチ才 グリコール酸処理によるジスルフィド結合の切断の影響 について娭討した。

\section{2. 実殹}

\section{1 試料睭紫}

7 才女より採取した，パーマ等の化学処理経験の無 い毛㸡を試料とした。ラウリル硫酸ナトリウム水溶液で 洗浄後，自然乾燥し，続いてアセトン洗浄を行った。毛 髪中のジスルフィド結合（S-S結合）を切断するために 行ったチオグリコール酸処理は，表1に示す調合により 調製した13\% wtチオグリコール酸アンモ二ウム水溶液 で，浴比 $1 ： 150 ， 25^{\circ} \mathrm{C}, 10$ 分間浸漬処理後，0.1\%夕 エン酸水溶液により反応を停止し，蒸留水で洗浄を行っ

Table 1 The Chemical Components of Treating Agent for Human Hair

\begin{tabular}{cc}
\hline Chemicals & Content \\
\hline Ammonium thioglicolate $(50 \%)$ & $13 \%$ \\
EDTA & $0.1 \%$ \\
Water & $86.9 \%$ \\
Aqueous ammonia & $\mathrm{pH}$ adjustment
\end{tabular}


た。この处理を 4 回繰り返して行い，自然乾燥後，チオ グリコール酸処理毛裂とした。

\section{2 方 法}

\subsection{1 的粘弾性 (DMA) 测定}

測定機器はセイコー電子工業社製，DMS200を用いた。 毛髪 5 本を荷重が均一に分担されるように注意して平行 に並ベ, 試料長 $10 \mathrm{~mm}$ とし, 引張モードで, 昇温速度 $1{ }^{\circ} \mathrm{C} / \mathrm{min}$ ，測定温度範囲 $-150 \sim 250{ }^{\circ} \mathrm{C}$ ，測定周波数 $0.5 ， 1 ， 2 ， 5 ， 10 \mathrm{~Hz}$ の 5 水準で測定を行った。但 し，水分の影響をみるため，末処理毛髮及びチオグリコ 一ル酸処理毛髪について,

A 試料を測定直前に $120{ }^{\circ} \mathrm{C} て ゙ 10$ 分間乾燥処理を行っ た場合（以後Dry 試料とする）。

$\mathrm{B}$ 標準状態 $\left(\mathrm{RH} 65 \% ， 20^{\circ} \mathrm{C}\right) に 3$ 日以上放置した試 料を測定した場合（以後 RH $65 \%$ とする），

C 試料を測定直前まで蒸留水に浸した場合（以後 Wet とする).

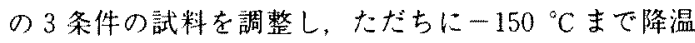
してDMA 測定老行った。

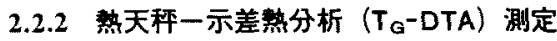

測定はセイコ一電子工業社製， $\mathrm{T}_{G}-\mathrm{DTA} 220 に よ り ，$ 昇温速度 $10^{\circ} \mathrm{C} / \mathrm{min}$ で, $25 \sim 500^{\circ} \mathrm{C}$ まで, 窒素䨌囲気中 で行った。

\subsection{3 示差走查熱量計（DSC）剆定}

ガラス転移温度 $(\mathrm{Tg})$ に及はす水の影響を検討する ため，セイコ一電子工業社製 DSC220により，昇温速度 10 “ $\mathrm{C} / \mathrm{min}$ で測定した。毛琵試料は細切してアルミニウ 么製の簡易密封パンに入れ，蒸留水を滴下し，水を試料 全体に馴染ませた上で過剩な水を蒸発させ，水分率を $4.6 ， 11.3 ， 17.2 ， 24.5 ， 34.5 \%$ に調整した。測定はパ ンを密封後48時間以上経過してから行った。測定終了後， パンに穴を開けて $120{ }^{\circ} \mathrm{C}$ まで舁温し，水分を無発させ て乾燥試料重量の測定を行い，正確な水分率を算出した。 水分率 $0 \%$ については, $150{ }^{\circ} \mathrm{C}$ まで昇温し, 水分を蒸 発させた試料で測定した。

毛珐中の不凍水量を測定するために，細切した毛垡試 料をDSC用アルミオープンパンにいれ，蒸留水を滴下 L Tg 測定の場合と同しくく，過剩な水を蒸発させること に上り，33.5，37.7，66.9\%に水分率在調整した。水分 率 $12.0 \%$ の試料は水を加元ず，通常喺境下にある試料を 用いた。測定はー80 - $200{ }^{\circ} \mathrm{C}$ まで，昇温速度 $10{ }^{\circ} \mathrm{C} / \mathrm{min}$ で行った。また水分率Wc（\%)は佺吸着水重量 (g)，乾燥試料重量 $(\mathrm{g}) 1 \times 100$ として算出した。不 凍水量は，融解及び結晶化ピークのエンタルピーから中 村らの方法 $[7,8]$ を用いて算出した。

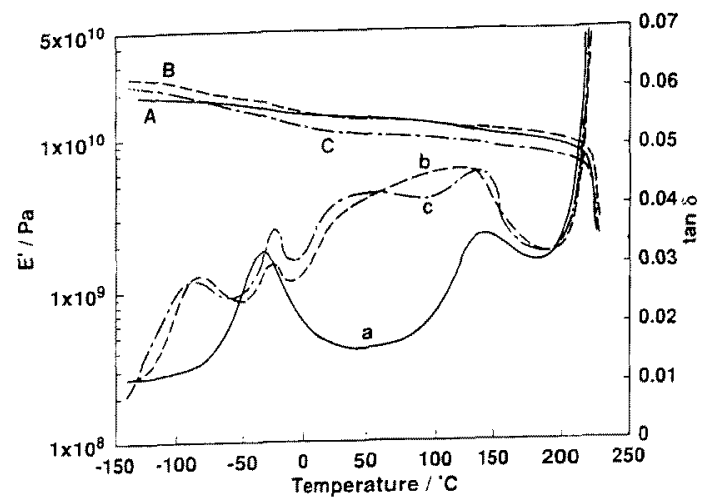

Fig. 1 DMA curves of $\mathrm{E}^{*}$ and $\tan \delta$ for untreated human hair.

$\mathrm{A}$ and a: dry state, $\mathrm{B}$ and $\mathrm{b}$ : $\mathrm{RH} 65 \%$ at $20^{\circ} \mathrm{C}, \mathrm{C}$ and $\mathrm{c}$ : wet state.

\section{3. 䊅果と考察}

人の毛髪の直径は約60１00 $\mu \mathrm{m}$ であり，非常に細い ため，単緎維状態での DMA 測定は装置の荷重限界を越 え測定可能範囲外となる。そこで $1 ， 3 ， 5 ， 10$ 本の毛 裂を平行に並べ測定を試みた結果，5本の場合に最も再 現性のあるデータが得られた。そこで以後このデータを 用いて議論を進めた。

図1に，化学処理を行っていない毛裂の含水率の異な る状態のDMA 曲線を示す。貯蔵弾性率（E'）は絶乾状 態 (Dry，A）ではー150〜200 ${ }^{\circ} \mathrm{C}$ まで単調に低下し, $230{ }^{\circ} \mathrm{C}$ 付近で急激に低下する。しかし標準状態（RH $65 \%$ ，B）の試料及び強制的に水を与えた試料（Wet,

C) のいず机の場合も水分が存在すると，Eは低温側で は比較的大きく減少しているが， $0{ }^{\circ} \mathrm{C}$ 付近でゆるやか になる変曲点がみられる。

tan $\delta$ は絶乾状態（Dry，a）では $140{ }^{\circ} \mathrm{C}$ 及びー $40{ }^{\circ} \mathrm{C}$ 付近をピータとして，2つの分散がみられる。一方水が 存在すると, $140{ }^{\circ} \mathrm{C}$ 付近の分散は低温側にショルダー ピークが現れてプロードになり（b，c），その立ち上が りが低温側にシフトしている。また， $-80^{\circ} \mathrm{C}$ 付近に新 たな分散が認められる。以㣪 $140^{\circ} \mathrm{C},-40^{\circ} \mathrm{C},-80^{\circ} \mathrm{C}$ 付近の分散ピークを，順に $\alpha$ 分散， $\beta$ 分散， $\gamma$ 分散とよ 今。

毛裂の分子满造と水の関係について考えると，毛矮を 構成するタンパク鎖中の親水基間には，乾燥状態では水 素結合が存在するが，水が存在すると親水基が水の吸着 サイトとなり，水素結合は切断された状態になる。 DMA 曲線で，水を含んだ毛髪でみられるー150〜0 ${ }^{\circ} \mathrm{C}$ のE'の急激な低下は，毛髪中の水が，昇温によって分子 


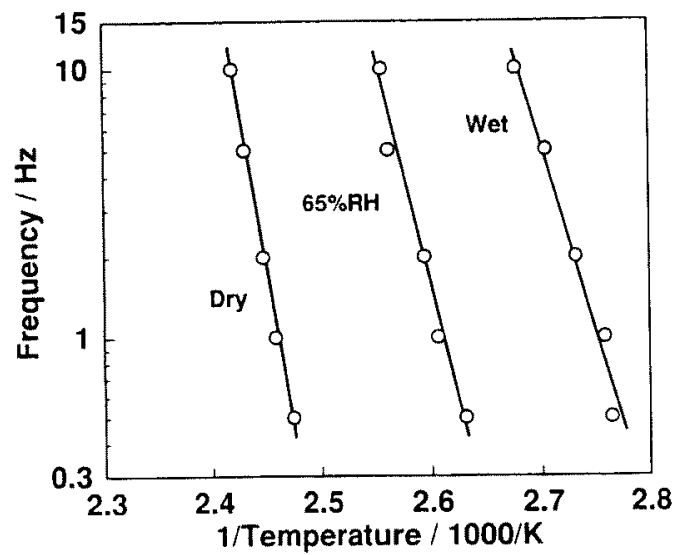

Fig. 2 Arrhenius plots of $\alpha$ dispersions of dry, RH65\% and wet states of untreated hair samples.

Table 2 Activation Energies $(\Delta \mathrm{E}, \mathrm{kJ} / \mathrm{mol}$ ) of $\alpha, \beta$ and $\gamma$ Dispersions of Untreated and Thioglicolic Acid-Treat. ed Human Hair

\begin{tabular}{|c|c|c|c|c|c|c|}
\hline \multirow[t]{2}{*}{ Condition } & \multicolumn{3}{|c|}{ Untreated $(\mathrm{kJ} / \mathrm{mol})$} & \multicolumn{3}{|c|}{$\begin{array}{l}\text { Thioglicolic } \\
\text { acid-treated }(\mathrm{kJ} / \mathrm{mol})\end{array}$} \\
\hline & $a$ & $\beta$ & $\gamma$ & $a$ & $\beta$ & $\gamma$ \\
\hline Dry & 447.4 & 130.7 & - & 378.3 & 159.6 & - \\
\hline RH $65 \%$ at $20^{\circ} \mathrm{C}$ & 304.3 & 189.7 & 50.8 & 378.3 & 159.6 & 53.3 \\
\hline Wet & 251.2 & 131.2 & 44.7 & 227.1 & 84.5 & 31.6 \\
\hline
\end{tabular}

運動を活発にし可塑化効果が現れるために起こると考え られる。

图 2 に未処理試料の $\tan \delta$ の周波数依存性加求め たアレニウスプロットを示す。多少の乱れはあるが、は ほ直線上にのりこの直線の傾きから活性化エネルギー （ $\Delta \mathrm{EkJ} / \mathrm{mol} ）$ 計算した。

表 2 にアレニウスプロットから計算した各分散の活性 化エネルギーを示す。 $\alpha$ 分散は活性化エネルギーが約 $250 \sim 450 \mathrm{~kJ} / \mathrm{mol}$ と大きく主鎖のミクロブラウン連動

(即ちガラス転移) と考えられる。图 1 で120 ${ }^{\circ} \mathrm{C}$ 付近 の $\alpha$ 分散は水分含有率の増加とともにブロードになり， ショルダーピークが現れて，立ち上がり温度が低温にシ フトしている(b，c）。これは乾燥試料である曲線 aで

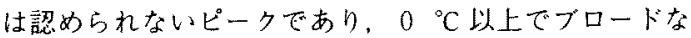
ピークとして現れていることから毛髮中の水分の蒸発に 伴ってショルダービークが生じると同時に，水の可塑化 効果により分子鎖がより少ないエネルギーで低温からミ タロブラウン運動を起こすことを示唆している。このこ とは水によって水素結合が切断された毛坺では，分子鎖 が運動しやすい状態にあることを裏付けている。また表

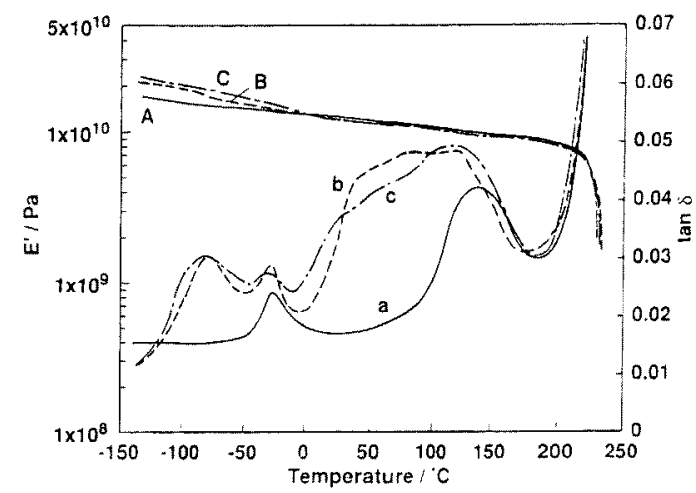

Fig. 3 DMA curves of $\mathrm{E}^{\prime}$ and $\tan \delta$ for thioglicolic acid'-treated human hair.

$\mathrm{A}$ and a: dry state, $\mathrm{B}$ and b: $\mathrm{RH} 65 \%$ at $20{ }^{\circ} \mathrm{C}, \mathrm{C}$ and $\mathrm{c}$ : wet state.

2 でß分散の活性化エネルギーは，未処理，チオダリコ ール酸処理共に, DRYよりも RH $65 \%$ の方が大きくな っている。この現象は，毛髢にとって自然な状態に近い 吸湿状態では，含まれる水は後で述べるように，すべて 不凍水として分子状態で存在しているため， $\beta$ 分散の関 与する局所の構造が，安定するためではないかと考えら れる。

図 3 に示すように，チオグリコール酸により還元処理 を行った毛裂の場合，DMA 曲線への水の影響は，末処 理の場合と比較して $\delta$ 曲線に $\gamma$ 分散が認められること等，類似していた。千 オグリコール酸還元処理では，毛髮中のジスルフィド結 合 $(S-S$ 結合) が切断されているが、この影響とみられ るのは， $\alpha$ 分散の立ち上がり温度が未処理の場合よりも 若干低温にシフトしていることや，特に乾燥試料の $\beta$ 分

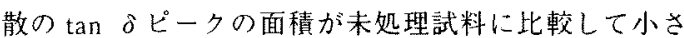
くなっている点である。水の存在が $\alpha$ 分散， $\gamma$ 分散に与 える影響を比較すると，毛髪のDMA 曲線には，化学処 理によるS-S結合の切断よりも，水による水素結合の 切断の方が大きく影響するといえる。

毛髪を構成するタンパク質は21種のアミノ酸から成る が， $S-S$ 結合を構成するシスチン等の含硫アミノ酸の含 量は約16一20\%であると報告されている $[9 ， 10]$ 。才才 グリコール酸処理によって S S 結合による架橋が必ず しもすべて切断されるわけではない上，水素結合に関わ る親水性側鎖やペプチド結合は $S-S$ 結合上りも多く存 在すること等を考慮すれば，チオグリコール酸処理によ るS-S結合の切断より，水による水素結合の切断の方 が毛髮の粘弾性特性に及ほす影響は大きいと考えられる。 さらにß分散について分子構造との関倸を考える上， 


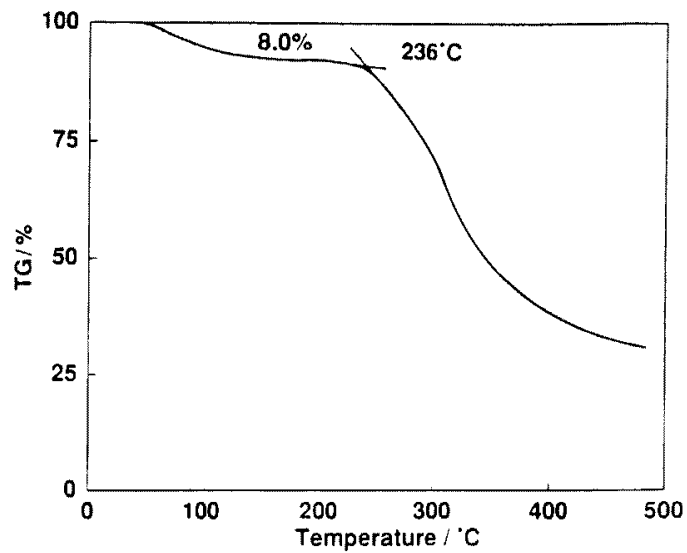

Fig. $4 T_{G}$.DTA curves of untreated human hair.

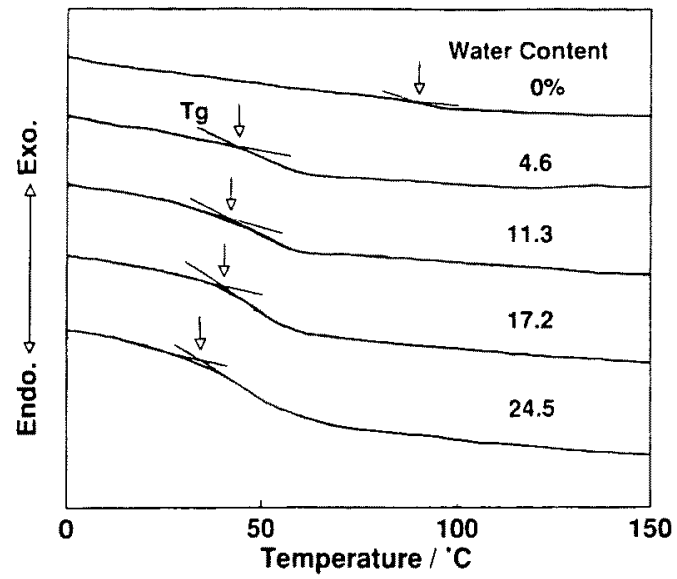

Fig. 5 DSC curves of human hair containing various water content

イロンやポリアミノ酸に関する研究では，水が存在する ときに現れる，側鎖の動きであるとされているが $[11,12,13,14]$, 毛彭の場合は，水の存在にも， $S-S$ 結 合の切断にも影響を受けていない。したがって $\beta$ 分散は、 水素結合の関与しない，主鎖の局所的な部分の運動であ ると考えられる。一方妢散はナイロン等のポリアミド ではメチレン基の局所的な運動とする報告が多いが (11-13，15，16]，水の存在によって現れるためこの考文 かたはあてはまらず，水素結合の切断によって生じる側 鎖の運動であると考えられる。

図 4 に空温状態の毛秡についての $\mathrm{T}_{\mathrm{G}}$-DTA 测定の結 果を示す。室温付近から㕷温すると，毛髪の吸着水の蔒 発による約 $8 \%$ の減量が生じる。このことからも，図 1 ， 3に示した水分を含んだ毛垡のDMA曲線で現れる， $\alpha$ 分散のショルダービークが，水の蒸発と同時に起こって いることが明らかである。これは，後に述べる図７の水

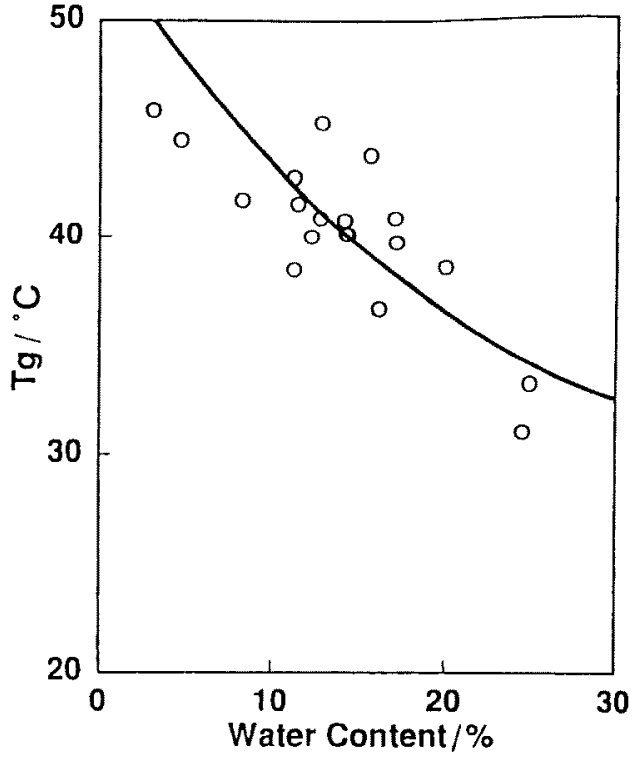

Fig. 6 Relationship between glass transition tempera. tures (Tg's) of human hair and water content.

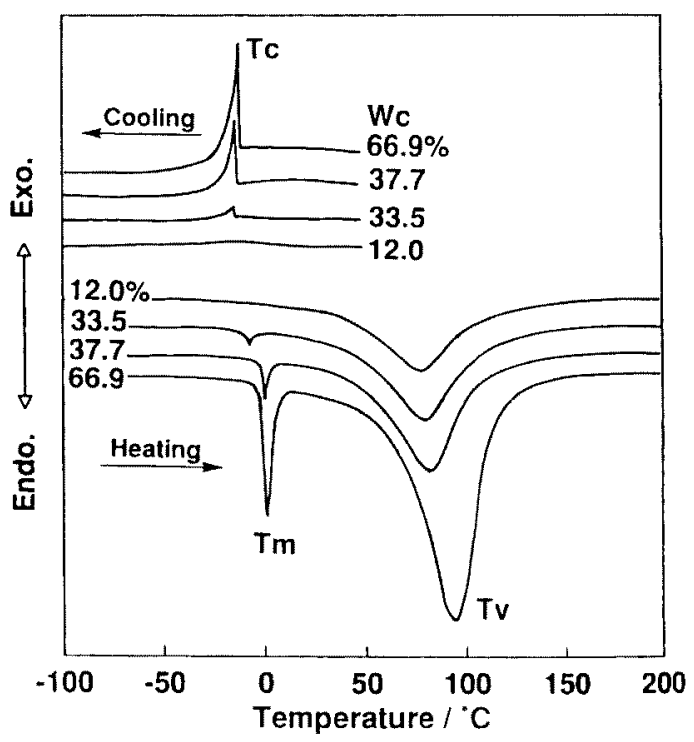

Fig. 7 DSC curves of water sorbed on human hair.

分率 $12 \%$ の試料の DSC 曲線で，水の蒸発が観測される ことからも明らかである。

図 5 岋異なる水分率をもつ毛敨のガラス転移付近の DSC 曲線を示す。ここでは密封パンを用いて、温度上 昇による系外への水の蒸発をおさえている。水分率 $0 \%$ の乾燥試料のガラス転移温度（Tg）は，熱容量のギャ ップは小さいが90 ${ }^{\circ} \mathrm{C}$ 付近に見られる。しかし吸着水が 共存すると、いずれも $40^{\circ} \mathrm{C}$ 付近にベースラインの移動 
が見られる。図に示すように熱容量のギャップの生じる 温度を接線の交点から求め, $T \mathrm{~g}$ とした。図から明らか なように，水分の增加に伴って Tg が低下する傾向がみ られる。図6に毛琶の $\mathrm{Tg}$ と水分含有率の関係を示す。 $\mathrm{Tg}$ は毛髮内の吸着水の增加と共に低下し，水に影警さ れることは明らかである。しかし水分率が $30 \%$ 越える と，水の增加による $\mathrm{Tg}$ の低下が小さくなる傾向が認め られた。この現象は，毛等のガラス転移に強く影锌する 吸着水は約30\%であることを示唆している。

図 7 は，毛髮内の水分の熱的挙動を調べるため，強制 的に水をあたえて水分率をコントロールした毛緜で，中 村らの方法 [7，8]により，束縺水量を定量するため， DSC 測定を行った結果である。これは図6で観測され た30\%の水分子が毛裂中のタンパク質分子とどのような 相互作用をもっているのかを検討するため行った。

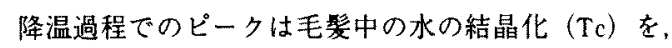
昇温過程の $0{ }^{\circ} \mathrm{C}$ 付近のビークは融解 $(\mathrm{Tm}), 100{ }^{\circ} \mathrm{C}$ 付 近のブロードなピークは蒝発（TV）を示している。通 常環境下の毛髮試料である12\%の DSC 曲線は, 蒸発ピ 一クがみられるだけで，毛裂内の水はすべて結晶化せず, 毛髮のタンパク分子鎖に束縛された不凍水となることを 示している。しかし水分率が $30 \%$ を越えると，水の結晶 化及び融解ピークが観測され，自由水が存在することが わかる。一般的に親水性高分子の吸着水 $(\mathrm{Wc})$ 熱分 析すると, 自由水 (Wf), 不凍水 (Wnf), 及び結晶化 する束縛水 $(\mathrm{Wfb})$ の3つに分類でき，

$W_{c}=W f+W n f+W f b$

で表される。高分子に强く束縛された束縛水（Wb）は， 束縛水二不凍水十結晶化する束縛水であり，

$\mathrm{Wb}=\mathrm{Wnf}+\mathrm{Wfb}$

で表走れ，式了，2から，

$\mathrm{Wb}=\mathrm{Wc}-\mathrm{Wf}$

によって計算きれる。しかし毛髮一水系の場合式 $2 の$ Wfb DSC曲線に観測されないため，水は自由水と不 凍水に 2 分され, 束糐水量は不凍水量と等しくなり, 式 4 加不凍水量か計算される。

$\mathrm{Wnf}=\mathrm{Wc}-\mathrm{Wf}$

表 3 にDSC 曲線から算出した不凍水量を示す。不凍 水量 $(\mathrm{Wnf})$ は水分率 $(\mathrm{Wc})$ によらず的 $30 \%$ あっった。

以上の結果加ら，毛髮の不凍水量は $\mathrm{Tg}$ と水分率の関 係において，Tgの低下が小さくなる水分率（約30\%） と一致する。つまり，Tgの低下に影晦する水は，全て 不凍水=束縛水であり，タンパク質の分子鎖中の親水基 に強く束縛された状態で存在すると考えられる。このよ うに毛坺の物性に及はす水の影笪はすべて束縛水による もので，自由水による影翌はないということが明らかで
Table 3 Non-Freezing Water Content (Wnf) at Various Water Content $\left(W_{c}\right)$ of Human Hair Calculated from DSC Curves

\begin{tabular}{cc}
\hline We $(\%)$ & Wnf $(\%)$ \\
\hline 12.0 & $(12.0)$ \\
33.5 & 32.2 \\
37.7 & 31.0 \\
66.9 & 28.4 \\
\hline Ave. & 30.5 \\
\hline
\end{tabular}

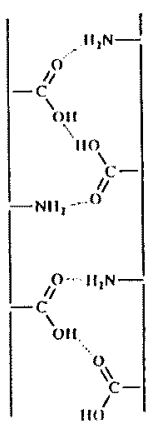

A

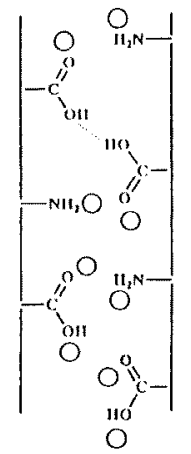

B

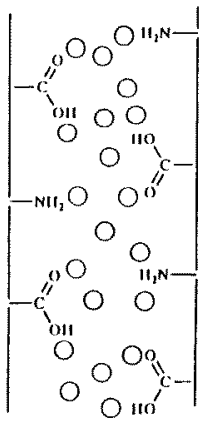

C
Fig. 8 The schematic models of molecular structure between protein of human hair and water molecules A dry state, B: RH $65 \%$ at $20^{\circ} \mathrm{C}$. C: wet state

ある。この現象は既に合成高分子の $\mathrm{Tg}$ や強度に及ぼす 水の影響でも明らかになっている[17-19]。

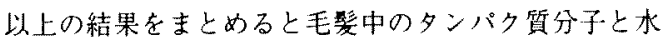
分子の関係は図 8 に示すようなモデルで表せると考えら れる。图のA：Dryでは毛髮中に水が存在しない状態を 示しており，主鎖のタンパタ質分子間には水素結合が多 数存在するため, 分子鎖は運動しにくい状態にある。B の標準状態ではモデル図中に示すように適当量の水（約 $10 \%$ )か存在し，これらは水素結合切断して吸着サイ トである親水基に束縛される。しかし一部は水分子によ る影䈉がなく架橋を形成した状態にあると考えられる。 このとき，主鎖間の結合がゆるやかになるため分子鎖は 動きやすくなり，主鎖の運動の開始点である $\mathrm{Tg}$ が低下 寸る要因上なる。また，C：Wet（水分率30\%以上）の 場合は，承の量が過剩になり吸着サイトの許容量を越之， 過剩な水は自由水として存在するようになる。この場合， 水素結合は既に全て切断されているため自由水は Tgに は影幣しなくなると考えられる。

以上のように毛髪ー氷系の粘弾性測定及び示差熱測定 
により，毛誉の分子運動に及はす水の影響が明らかにな るとともに，その影辢する水分子は全て束輔水であり， 自由水による影響は認められないことが分かった。

本研究の一部は, 平成 6 年度䄉維学会年次大会研究発 表会 (平成 6 年 7 月，東京）で発表した。

\section{文献}

1. C. R. Robbins and C. Kelly, J. Soc. Cosmetic Chemists, 20, 555, (1969)

2. J. A. Swift and B. Bews, $J$. Soc. Cosmetic Chemists, 25. 355. (1974).

3. 円山朋子, 神戸哲也, 鳥居健二, 粧技誌, 27, 144, (1993).

4、熱田智香，太田裕子，栗村勝樹，瀧川敏算，升田利 志郎，日本バイオレオロジー学会誌，7，31 (1993).

5. K. Nakamura, T. Hatakeyama, and H. Hatakeyama, Text. Res. J.. 53, 682, (1983).

6. 中村邦雄，熱測定，18，244，(1991）。

7. K. Nakamura, T. Hatakeyama, and H. Hatakeyama, Text. Res. J., 51, 607, (1981).

8. K. Nakamura, T. Hatakeyama, and H. Hatakeyama, Polymer, 24, 871 (1983).
9. タローレンス・ R・ロビンス, 「毛姴の科学」, フレ グランスジャーナル社，24，(1982).

10. J. A. Swift and B. Bews, J. Soc. Cosmet. Chem., 25, 13, (1974).

11. E. Ong, Y. Kim, and H. L. Williams, J. Appl. Polm. Sci., 31. 367 (1986)

12. S. Yano and M. Murayama, J. Appl. Polym. Sci., 25, 433 (1980).

13. T. Kawaguchi, J. Appl. Polym. Sci., 2, 56 (1959).

14. A. Tsutsumi, K. Hikichi, T. Takahashi, Y. Yamashita, N. Matsushima, and M. Kanke, J. Macromol. Sci. Phys., B8, 413 (1973).

15. C. Garbuglio, G. Ajroldi, T. Casiraghi, and G. Vittadini, J. Appl. Polym. Sci., 15, 2487 (1971).

16. V. Frosini and E. Butta, J. Polym. Sci. Polym. Lett., 9. 253 (1971).

17. 中村邦雄, 畠山立子, 䋐維と工業，41，369, (1985).

18. H. Batzer and U. T. Kreibich, Polym. Bull., 5, 585 , (1981).

19. T. Hori, H. Zhang, T. Shimizu, and H. Zollinger, Text. Res. J., 58, 227. (1988). 